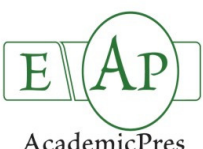

\title{
Identification of Discriminant Factors after Exposure of Maize and Common Bean Plantlets to Abiotic Stresses
}

\author{
Lázaro HERNÁNDEZ ${ }^{1}$, Octavio LOYOLA-GONZÁLEZ ${ }^{1}$, Bárbara VALLE ${ }^{1}$, \\ Julia MARTÍNEZ ${ }^{1}$, Leyanes DÍAZ-LÓPEZ ${ }^{1}$, Carlos ARAGÓN ${ }^{1}$, Oscar VICENTE², \\ Jutta PAPENBROCK ${ }^{3}$, Richard TRETHOWAN ${ }^{4}$, Lourdes YABOR ${ }^{1}$, \\ José Carlos LORENZO ${ }^{1 *}$
}

\author{
IUniversidaddeCiegodeAvila,CentrodeBioplantas,CiegodeAvila69450,Cuba;lazaro@bioplantascu; octavioloyola@bioplantascu;bvalle@bioplantascu; \\ jmartinez@bioplantas.cu;leyanes@bioplantas.uj;cearagon79@gmail.com; lyabor@bioplantascu;jclorenzo@bioplantas.u(*orrespondingauthor) \\ ${ }^{2}$ Universitat Politécnica de Valencia, Institute of Plant Molecular and Cellular Biology (IBMCP, UPV-CSIC), Camino deVeras/m, 46022 Valencia, Spain; ovicente@ibmcp.upv.es \\ ${ }^{3}$ LeibnizUniversity Hannover, Instituteof Botany, HerrenhaeuserStr.2,D-30419Hannover, Germany;;utta.Papenbrock@botanik.uni-hannover.de \\ ${ }^{4}$ The University of Sydney, Plant BreedingInstitute, Faculty of AgricultureandEnvironment,Australia; richard.trethowan@sydney.edu.au
}

\begin{abstract}
Adverse environmental conditions limit crop yield and better understanding of plant response to stress will assist the development of more tolerant cultivars. Maize and common bean plantlets were evaluated under salinity, high temperature, drought and waterlogged conditions to identify biochemical markers which could be useful for rapid identification of putative stress tolerant plants. The levels of phenolics (free, cell wall-linked, total), aldehydes including malondialdehyde and chlorophylls $(a, b$, total) were measured on stressed plantlets. Only two indicators were statistically non-significant: chlorophyll $b$ in maize plantlets stressed with sodium chloride and malondialdehyde content in drought stressed maize. The most remarkable effects of abiotic stresses can be summarized as follows: (i) salinity increased levels of free phenolics in maize plantlets and chlorophylls $\left(a, b\right.$, total) in common bean; (ii) high temperature $\left(40^{\circ} \mathrm{C}\right)$ elevated levels of chlorophylls $(a, b$, total) in maize but decreased chlorophylls $(a, b$, total) and free phenolics in common bean; (iii) drought increased phenolics and decreased chlorophylls $(a, b$, total) in maize and increased chlorophyll pigments $(a, b$, total) in common bean; (iv) waterlogging increased free phenolics and decreased chlorophylls $(a, b$, total) in maize and increased chlorophyll ( $a$, total) in common bean. Free phenolics and chlorophylls, especially $a$, were the most responsive indicators to stress and can, therefore, be considered putative biochemical markers for abiotic stress tolerance in maize and common bean. The use of Fisher's linear discriminant analysis to differentiate non-stressed and stressed plants in breeding programs is also a novel aspect of this report. Fisher's linear discriminant functions classified correctly $100 \%$ of non-stressed or stressed originally grouped plants.
\end{abstract}

Keywords: abiotic stress, biochemical markers, genetic improvement, Phaseolus vulgaris, Zea mays

\section{Introduction}

Adverse environmental conditions, such as salinity, high temperature, drought and waterlogging, limit the geographical distribution of plant species and crop yield (Osmond et al., 1987). Predicted climatic change, population growth and the importance of sustainable food production makes the development of stress tolerant crop cultivars a high-priority globally (Zhu, 2001). Maize is the second most important agricultural crop globally. It is a human and livestock food and also used in the processing of industrial goods (Qing et al., 2009). Global maize production in 2011 exceeded 700 million tons (FAOSTAT, 2013). However, legumes also play a critical role in human and animal diets and contribute to sustainability by maintaining soil fertility (Tilman et al., 2002). The protein content of grain legumes can be three times that of cereal grains, thus a significant proportion of human protein and nutritional requirements can be supplied by legumes (Gepts et al., 2005). Common bean (Phaseolus vulgaris L.), one of the world's most important grain legumes, is consumed as a dietary staple worldwide, particularly in Latin America and Africa (FAOSTAT, 2013).

Efficient and effective genetic improvement of stress tolerance of crops such as maize and common bean requires easy to measure markers that have a higher heritability than 
590

the targeted abiotic stress trait (William et al., 2007). A number of biochemical markers have been reported for abiotic stresses. For example, salinity is associated with increases in abscisic acid (Shafi et al., 2011), proline (Benhassaini et al., 2012), glycine-betaine (Quan et al., 2004), polylols, sugar alcohols and soluble sugar concentrations (Gurmani et al., 2007). Salinity stress also decreases plant growth (Munns, 2005), nutrient uptake (Abdelgadir et al., 2005), $\mathrm{K}^{+}: \mathrm{Na}^{+}$ratio (Díaz-López et al., 2012a), stomatal aperture and density (Huang et al., 2009), hexoses, sucrose and starch (Arbona et al., 2005) and chlorophyll contents (Rivelli et al., 2012).

Moreover, high temperature stress is associated with increased lipid peroxidation (Silva et al., 2010b) and decreased photosynthesis (Ribeiro et al., 2009), $\mathrm{CO}_{2}: \mathrm{O}_{2}$ ratio in chloroplasts (Foyer and Noctor, 2000) and stomatal aperture (Ribeiro et al., 2004). Whereas drought stress is linked with increased abscisic acid (Gurmani et al., 2007), myo-inositol (Díaz-López et al., 2012b) and glycine-betaine levels (Quan et al., 2004); and decreased $\mathrm{CO}_{2}$ assimilation (Gindaba et al., 2004), relative water content (Galle et al., 2007), leaf turgor pressure (Schachtman and Goodger, 2008), osmotic potential (Silva et al., 2010a), starch content (Chao et al., 2006) and sugars and oligosaccharides (Anderson and Kohorn, 2001). Likewise, waterlogging is associated with increased free amino acids (Medina et al., 2009), abscisic acid (Xu et al., 2007), and $\mathrm{Na}^{+}$and $\mathrm{Cl}^{-}$concentrations (Wetson and Flowers, 2010), and decreased total biomass (Colmer and Voesenek, 2009), relative growth rate (Mielke et al., 2003), stomatal conductance and photosynthesis (Lopez and Kursar, 2003), $\mathrm{CO}_{2}$ assimilation (Gimeno et al., 2012), soluble sugars and starch concentration (Gimeno et al., 2012).

In a study of maize under salinity stress, Omoto et al. (2012) found that the activities of pyruvate orthophosphate dikinase, phosphoenolpyruvate carboxylase, NADPdependent malate dehydrogenase and NAD-dependent malate dehydrogenase, which are derived mainly from mesophyll cells, increased, whereas those of NADP-malic enzyme and ribulose-1,5-bisphosphate carboxylase / oxygenase, which are derived mainly from bundle sheath cells, decreased. In salt-treated plants, the photosynthetic metabolites malate, pyruvate and starch decreased by 40,89 and $81 \%$, respectively. Gas-exchange analysis revealed that the net photosynthetic rate, the transpiration rate, stomatal conductance and the intercellular $\mathrm{CO}_{2}$ concentration decreased strongly in salt-treated plants. Moreover, maize net photosynthesis was inhibited at leaf temperatures above $38^{\circ} \mathrm{C}$, transpiration rate increased progressively while nonphotochemical fluorescence quenching increased (CraftsBrandner and Salvucci, 2002). However, under drought stress a substantial decrease in gas exchange attributes (net photosynthetic rate, transpiration rate, stomatal conductance, water use efficiency, instantaneous water use efficiency and intercellular $\mathrm{CO}_{2}$ ) was observed in maize (Anjum et al., 2011).

Anaerobic treatment dramatically altered the patterns of gene expression in maize seedlings (Subbaiah and Sachs, 2002). During anaerobiosis pre - existing protein synthesis is immediately repressed, with the concurrent initiation of selective synthesis of approximately 20 proteins. Among these anaerobic proteins were enzymes involved in glycolysis and related processes. However, inducible genes that have different functions were also found; these may function in other, perhaps more long - term, processes of adaptations to flooding, such as aerenchyma formation and root - tip death (Subbaiah and Sachs, 2002).

In common bean, salinity had adverse effects not only on biomass yield and relative growth rate, but also on other morphological parameters such as plant height, number of leaves, root length and shoot/root weight ratio. Photosynthesis, transpiration rate and stomatal conductance were also adversely affected (Gama et al., 2007). In contrast, high temperature that exceeds optimal growth conditions tends to decrease both $\mathrm{NO}_{3}{ }^{-}$uptake and $\mathrm{N}_{2}$ fixation (Hungria and Kaschuk, 2014). Drought stress reduces leaf water potential and gas-exchange characteristics $\left(\mathrm{CO}_{2}\right.$ assimilation, stomatal conductance) (Fenta et al., 2014). It has been suggested that nodule characteristics and symbiotic nitrogen fixation ability should be included with above- and below-ground traits as phenotypic markers in germplasm evaluation and breeding programs aimed at improving drought tolerance in common bean (Fenta et al., 2014). Flooding tends to reduce root dry weight, leaf area and total chlorophyll content in common bean (Celik and Turhan, 2011).

This work focuses on two of the most important grain crops in Cuba and many other countries: maize and common bean. Our aim was to identify previously unreported biochemical markers for tolerance to salinity, high temperature, drought and waterlogging, which could be used for the rapid identification of putative stress tolerant maize and common bean plants in crop breeding programs. Stress screening was conducted on young plantlets; a method that allows large numbers of plants to be inexpensively screened. These protocols will therefore be attractive to crop breeding programs. We measured phenolics, aldehydes and chlorophylls to examine their expression in maize and common bean under abiotic stress. Data collected were used to generate Fisher's linear discriminant functions and differentiate non-stressed and stressed plants.

\section{Materials and Methods}

Survival response to different levels of stress

After harvesting in Ciego de Avila, Cuba (2012), maize (cv. 'Tuzón') and common bean (cv. 'Milagro Villaclareño') seeds were stored at $4^{\circ} \mathrm{C}$ in the dark in hermetically closed containers. Seeds at $12 \%$ moisture content based on fresh weight (ISTA, 2005) were stored. Seeds of maize and common bean were sown in plant containers $\left(200 \mathrm{~cm}^{3}\right.$ of ferralitic red soil collected in Ciego de Avila, Cuba, $\mathrm{pH} 6.8$, conductivity: $0.88 \mathrm{~S} \mathrm{~cm}^{-1}, 3$ seeds per container) and allowed to germinate and grow in a growth chamber at $28{ }^{\circ} \mathrm{C}$ before the imposition of stress treatments. The photosynthetic photon flux density was $800 \mu \mathrm{mol} \mathrm{m} \mathrm{s}^{-1}$. Chemical fertilizers were not used and each plant container was irrigated with $25 \mathrm{ml}$ water daily for $10 \mathrm{~d}$. After $10 \mathrm{~d}$ the plantlets were subjected to different stress treatments using five containers per treatment.

Salt stress was imposed by irrigating each pot daily with $25 \mathrm{ml}$ of $\mathrm{NaCl}$ solution at increasing concentrations $(200,400,600$ and $800 \mathrm{mM}$ ) - or with water in the non-stressed controls - and 


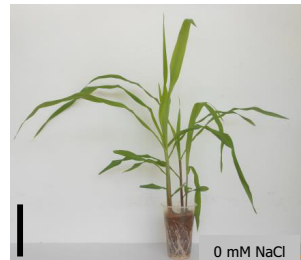

A Maize
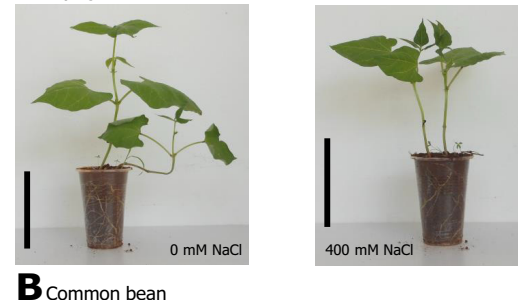

$400 \mathrm{mM}$ Nacl 2

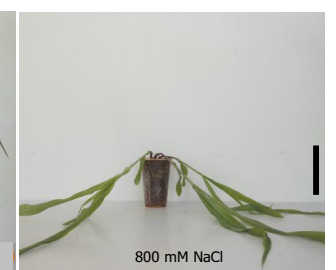

$800 \mathrm{mM} \mathrm{NaCl}$

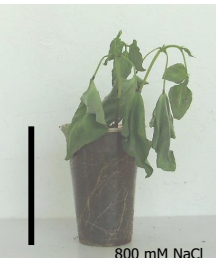

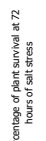

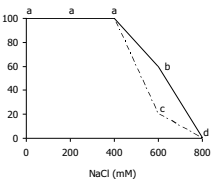

$\mathbf{C}_{\text {Interaction of the two experimental factors: plant }}^{\text {Maire }}$ specie and sodium chloride dosage. Original data were transformed for the statistical analysis according to $y^{\prime}=2^{*} * \arcsin (y / 100)^{0.5}$. Results with the same /etter are not statastically different (Two-Way ANOVA, Tukey, p $>0.05$ ).

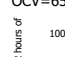

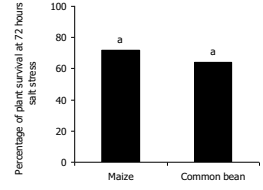

D Independent factor: plant specie. Results with the same letter are not statistically different. $0 c \mathrm{c}=8.31 \%$.

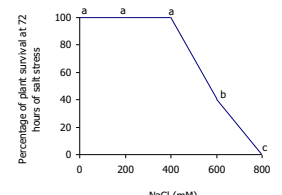

$\mathbf{E}_{\text {Independent factor: sodium chloride dosage. Results }}$ with the same letter are not statistically different.
OCV $=67.71 \%$.

Fig. 1. Effect of sodium chloride on maize and common bean plantlets. Seeds were allowed to germinate and grow without salt stress during 10 days, then plantlets were stressed during 72 hours. Each plant container was irrigated every day with $25 \mathrm{ml}$ water (without or with $\mathrm{NaCl}$ ). In each photograph, black vertical bars represent $10 \mathrm{~cm}$. Pot volume $=200 \mathrm{~cm}^{3}$. Substrate: Ferralitic red soil. In C, D and E, OCV means Overall Coefficient of Variation $=(\text { Standard deviation/Average })^{*} 100$. To calculate this coefficient, average values of each treatment were considered. The higher difference between the treatments compared, the higher the OCV

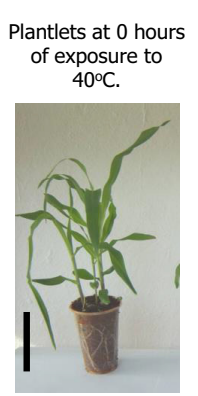

$\mathbf{A}_{\text {Maize }}$

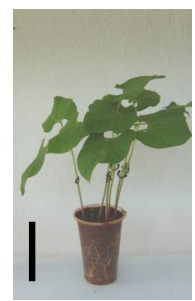

B common bean
Plantlets at 6 hours of exposure to

$40^{\circ} \mathrm{C}$.
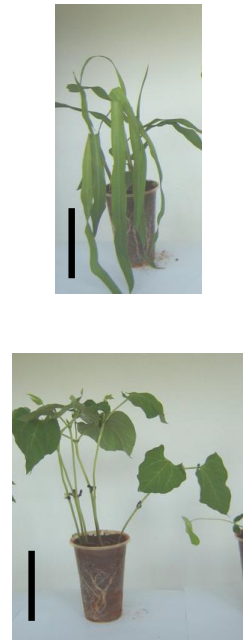

.
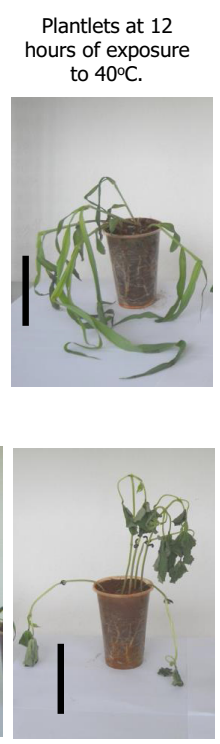

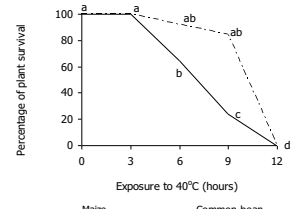

\section{$\mathbf{C}_{\text {In }}$} (hours)

C Interaction of the two experimental factors: plant specie and time of exposure to $40^{\circ} \mathrm{C}$. Original data were $y^{\prime}=2 *$ arcsin $(y / 100)^{0.5}$. Results with the same $/$ tter ang to statistically different (Two-Way ANOVA, Tukey, $p>0.05$ ). OCV $=63.70 \%$.

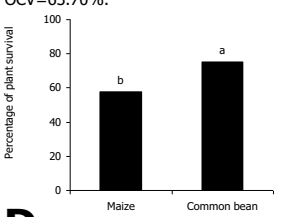

D Independent factor: plant specie. Results with the same letter are not statistically different. $\mathrm{OCV}=18.74 \%$.

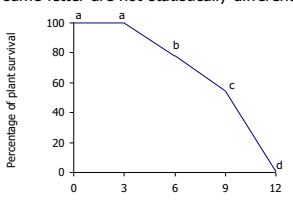

$\mathbf{E}_{\mathrm{In}}$ Exposure to $40^{\circ} \mathrm{C}$ (hours)

Independent factor: time of exposure to $40^{\circ} \mathrm{C}$. Results with the sam
$\mathrm{OCV}=62.79 \%$.

Fig. 2. Effect of exposure to high temperature $\left(40^{\circ} \mathrm{C}\right)$ on maize and common bean plantlets. Seeds were allowed to germinate and grow without high temperature stress $\left(28^{\circ} \mathrm{C}\right)$ during 10 days, then plantlets were exposed to $40{ }^{\circ} \mathrm{C}$ during 12 hours. In each photograph, black vertical bars represent $10 \mathrm{~cm}$. Pot volume $=200 \mathrm{~cm}^{3}$. Substrate: Ferralitic red soil. In C, D and E, OCV means Overall Coefficient of Variation $=(\text { Standard deviation } / \text { Average })^{*} 100$. To calculate this coefficient, average values of each treatment were considered. The higher difference between the treatments compared, the higher the OCV 

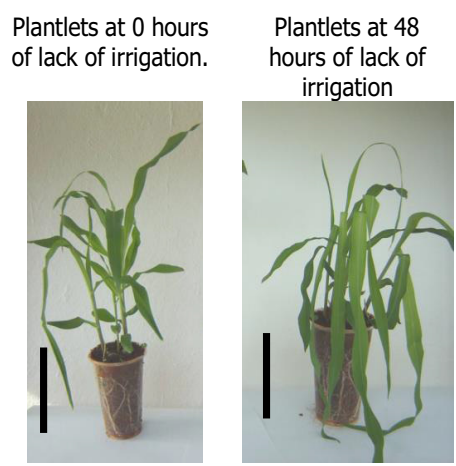

$\mathbf{A}_{\text {Maize }}$

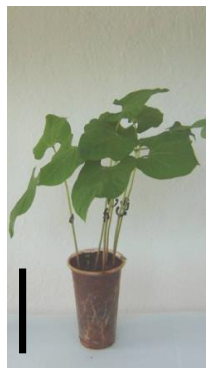

B Common bean
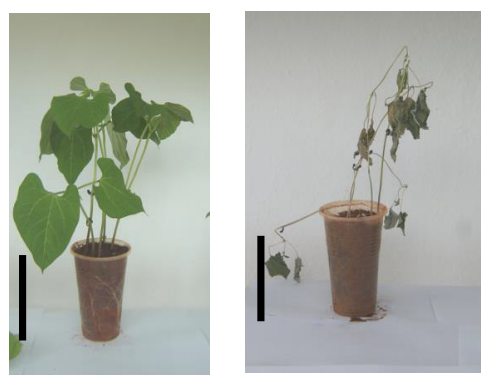

Plantlets at 96 hours of lack of irrigation.

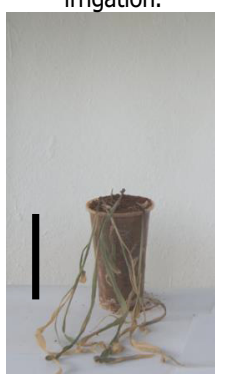

C

(1)

Interaction of the two experimental factors: plant specie and time of lack of irrigation. Original data were transformed for the statistical analysis according to $\mathrm{y}^{\prime}=2 * \arcsin (\mathrm{y} / 100)^{0.5}$. Results with the same letter are not

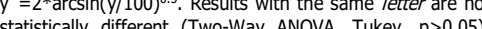
statistically different (Two-Way ANOVA, Tukey, $\mathrm{p}>0.05$ ).

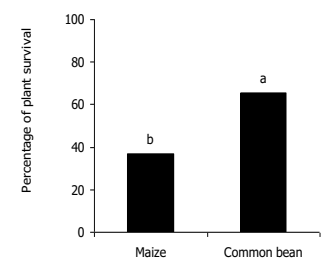

D Independent factor: plant specie. Results with the same letter are not statistically different. OCV $=39.77 \%$.

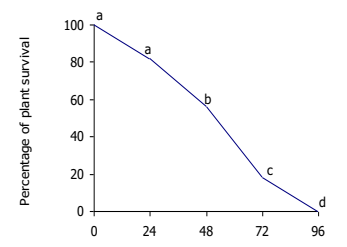
Lack of irrigation (hours)
with the same letter are not statistically different.
$\mathrm{OCV}=82.15 \%$.

Fig. 3. Effect of lack of irrigation on maize and common bean plantlets. Pots were irrigated every day with $25 \mathrm{ml}$ water during 10 days, then watering was suspended. In each photograph, black vertical bars represent $10 \mathrm{~cm}$. Pot volume $=200 \mathrm{~cm}^{3}$. Substrate: Ferralitic red soil. In C, $\mathrm{D}$ and E, OCV means Overall Coefficient of Variation $=(\text { Standard deviation/Average })^{*} 100$. To calculate this coefficient, average values of each treatment were considered. The higher difference between the treatments compared, the higher the OCV

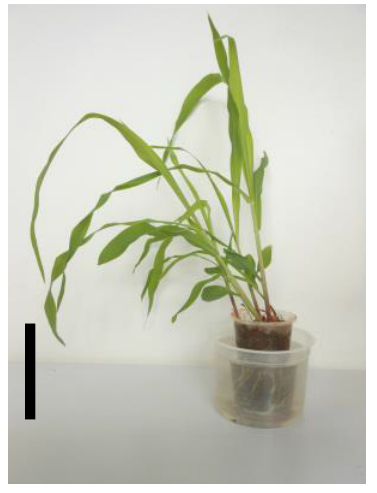

$\mathbf{A}_{\text {Maize }}$

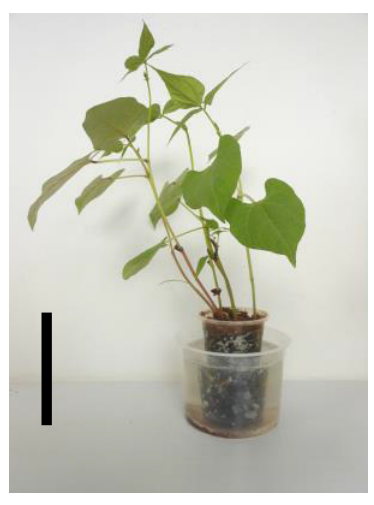

B common bean

Fig. 4. Effect of flooding on maize and common bean plantlets. Pots were irrigated every day with $25 \mathrm{ml}$ water during 10 days, then pots were immersed into $350 \mathrm{ml}$ water during 10 days but plant survival was not affected as shown in these photographs. In each photograph, black vertical bars represent $10 \mathrm{~cm}$. Plant pot volume $=$ $200 \mathrm{~cm}^{3}$. Substrate: Ferralitic red soil

percentage plantlet survival was recorded after $72 \mathrm{~h}$. Heat stress was generated by exposing plantlets to $40{ }^{\circ} \mathrm{C}$ for $12 \mathrm{~h}$ and survival was assessed every $3 \mathrm{~h}$ of treatment. Drought stress was imposed by suspending watering for $96 \mathrm{~h}$; during this period, plantlet survival was registered every $24 \mathrm{~h}$. Finally, to assess the effect of waterlogging, pots were immersed in $350 \mathrm{ml}$ water for an additional $10 \mathrm{~d}$ and survival rates were determined every $24 \mathrm{~h}$ during this period.

\section{Biochemical changes induced by stresses}

Phenolics, aldehydes and chlorophylls were assessed in stresstreated maize and common bean plantlets ten days after sowing. Plantlets otherwise maintained under the conditions described above, were either treated with $567 \mathrm{mM} \mathrm{NaCl}$ for $72 \mathrm{~h}$ (salt stress), exposed to $40{ }^{\circ} \mathrm{C}$ for $9.3 \mathrm{~h}$ (heat stress), kept without irrigation for $51.8 \mathrm{~h}$ (water stress), or immersed in water $(350 \mathrm{ml}$ per pot) for 51.8 h. After treatment, middle-aged leaves were collected from the three plantlets of each container, pooled and ground in liquid nitrogen to a fine powder. Leaf material was similarly collected from the corresponding non-stressed controls. Three independent samples (1 g powder each) per treatment were used for all biochemical assays.

Chlorophylls $(a, b$, total) were quantified following Porra (2002), phenolics (free, cell wall-linked, total) by the method of Gurr et al. (1992), and malondialdehyde and other aldehydes as described 
Table 1. Effect of sodium chloride on maize and common bean plantlets at $72 \mathrm{~h}$ of salt stress $(567 \mathrm{mM} \mathrm{NaCl})$

\begin{tabular}{lcccc}
\hline \multirow{2}{*}{ Indicators evaluated in middle-aged leaves ${ }^{*}$} & \multicolumn{2}{c}{ Maize } & \multicolumn{2}{c}{ Common bean } \\
\cline { 2 - 5 } & $0 \mathrm{mM} \mathrm{NaCl}$ & $567 \mathrm{mM} \mathrm{NaCl}$ & $0 \mathrm{mM} \mathrm{NaCl}$ & $567 \mathrm{mM} \mathrm{NaCl}$ \\
\hline Free phenolics (mg gallic acid equivalents/g fresh mass) & $1.80 \mathrm{~b}$ & $14.94 \mathrm{a}$ & $9.69 \mathrm{~b}$ & $10.14 \mathrm{a}$ \\
\hline Cell wall-linked phenolics (mg gallic acid equivalents/g fresh mass) & $86.03 \mathrm{a}$ & $45.07 \mathrm{~b}$ & $43.82 \mathrm{~b}$ & $52.70 \mathrm{a}$ \\
\hline Total content of phenolics (mg gallic acid equivalents/g fresh mass) & $87.82 \mathrm{a}$ & $60.01 \mathrm{~b}$ & $53.52 \mathrm{~b}$ & $62.84 \mathrm{a}$ \\
\hline Malondialdehyde $(\mu \mathrm{M} / \mathrm{g}$ fresh mass) & $22.72 \mathrm{~b}$ & $34.66 \mathrm{a}$ & $55.30 \mathrm{a}$ & $43.65 \mathrm{~b}$ \\
\hline Other aldehydes $(\mu \mathrm{M} / \mathrm{g}$ fresh mass) & $81.14 \mathrm{~b}$ & $192.97 \mathrm{a}$ & $129.54 \mathrm{~b}$ & $157.94 \mathrm{a}$ \\
Chlorophyll $a(\mathrm{mg} / \mathrm{g}$ fresh mass) & $2.96 \mathrm{a}$ & $2.60 \mathrm{~b}$ & $0.23 \mathrm{~b}$ & $0.78 \mathrm{a}$ \\
\hline Chlorophyll $b$ (mg $/ \mathrm{g}$ fresh mass) & $1.78 \mathrm{a}$ & $1.82 \mathrm{a}$ & $0.53 \mathrm{~b}$ & $2.08 \mathrm{a}$ \\
\hline Total content of chlorophyll $(\mathrm{mg} / \mathrm{g}$ fresh mass) & $4.67 \mathrm{a}$ & $4.21 \mathrm{~b}$ & $0.79 \mathrm{~b}$ & $2.80 \mathrm{a}$ \\
\hline
\end{tabular}

${ }^{*}$ In each crop, results with the same letter are not statistically different ( $\mathrm{t}$-test, $\left.\mathrm{p}>0.05\right)$.

Table 2. Effect of exposure to high temperature $\left(40^{\circ} \mathrm{C}\right)$ on maize and common bean plantlets at $9.3 \mathrm{~h}$ of stress

\begin{tabular}{lcccc}
\hline \multirow{2}{*}{ Indicators evaluated in middle-aged leaves* } & \multicolumn{2}{c}{ Maize } & \multicolumn{2}{c}{ Common bean } \\
\cline { 2 - 5 } & $28{ }^{\circ} \mathrm{C}$ & $40{ }^{\circ} \mathrm{C}$ & $28{ }^{\circ} \mathrm{C}$ & $40{ }^{\circ} \mathrm{C}$ \\
\hline Free phenolics (mg gallic acid equivalents/g fresh mass) & $14.40 \mathrm{a}$ & $9.04 \mathrm{~b}$ & $6.54 \mathrm{a}$ & $1.12 \mathrm{~b}$ \\
Cell wall-linked phenolics (mg gallic acid equivalents/g fresh mass) & $82.39 \mathrm{a}$ & $47.96 \mathrm{~b}$ & $37.82 \mathrm{a}$ & $19.10 \mathrm{~b}$ \\
Total content of phenolics $(\mathrm{mg}$ gallic acid equivalents/g fresh mass) & $96.79 \mathrm{a}$ & $57.00 \mathrm{~b}$ & $44.37 \mathrm{a}$ & $20.22 \mathrm{~b}$ \\
Malondialdehyde $(\mu \mathrm{M} / \mathrm{g}$ fresh mass) & $27.58 \mathrm{a}$ & $23.33 \mathrm{~b}$ & $80.37 \mathrm{~b}$ & $84.82 \mathrm{a}$ \\
Other aldehydes $(\mu \mathrm{M} / \mathrm{g}$ fresh mass) & $164.62 \mathrm{a}$ & $88.63 \mathrm{~b}$ & $154.95 \mathrm{~b}$ & $365.73 \mathrm{a}$ \\
Chlorophyll $a(\mathrm{mg} / \mathrm{g}$ fresh mass) & $0.33 \mathrm{~b}$ & $3.05 \mathrm{a}$ & $4.18 \mathrm{a}$ & $0.25 \mathrm{~b}$ \\
Chlorophyll $b$ (mg/g fresh mass) & $0.38 \mathrm{~b}$ & $1.85 \mathrm{a}$ & $3.08 \mathrm{a}$ & $0.13 \mathrm{~b}$ \\
Total content of chlorophyll $(\mathrm{mg} / \mathrm{g}$ fresh mass) & $0.77 \mathrm{~b}$ & $4.81 \mathrm{a}$ & $7.27 \mathrm{a}$ & $0.35 \mathrm{~b}$ \\
\hline
\end{tabular}

*In each crop, results with the same letter are not statistically different ( $\mathrm{t}$-test, $\mathrm{p}>0.05)$.

Table 3. Effect of drought on maize and common bean plantlets at $51.8 \mathrm{~h}$ of stress

\begin{tabular}{|c|c|c|c|c|}
\hline \multirow{2}{*}{ Indicators evaluated in middle-aged leaves* } & \multicolumn{2}{|c|}{ Maize } & \multicolumn{2}{|c|}{ Common bean } \\
\hline & $25 \mathrm{ml}$ water/day & Lack of irrigation & $25 \mathrm{ml}$ water/day & Lack of irrigation \\
\hline Free phenolics (mg gallic acid equivalents/g fresh mass) & $1.80 \mathrm{~b}$ & $11.96 \mathrm{a}$ & $9.69 \mathrm{~b}$ & $12.15 \mathrm{a}$ \\
\hline Cell wall-linked phenolics (mg gallic acid equivalents/g fresh mass) & $86.03 a$ & $56.02 b$ & $43.82 \mathrm{~b}$ & $46.21 \mathrm{a}$ \\
\hline Total content of phenolics (mg gallic acid equivalents/g fresh mass) & $87.82 \mathrm{a}$ & $67.97 \mathrm{~b}$ & $53.52 b$ & $58.36 \mathrm{a}$ \\
\hline Malondialdehyde ( $\mu \mathrm{M} / \mathrm{g}$ fresh mass) & $22.72 \mathrm{a}$ & $23.67 \mathrm{a}$ & $55.30 \mathrm{~b}$ & $95.98 \mathrm{a}$ \\
\hline Other aldehydes ( $\mu \mathrm{M} / \mathrm{g}$ fresh mass) & $81.14 \mathrm{~b}$ & $148.36 \mathrm{a}$ & $129.54 b$ & $278.79 \mathrm{a}$ \\
\hline Chlorophyll $a$ (mg/g fresh mass) & $2.96 \mathrm{a}$ & $0.55 b$ & $0.23 b$ & $3.83 a$ \\
\hline Chlorophyll $b$ (mg/g fresh mass) & $1.78 \mathrm{a}$ & $0.33 b$ & $0.53 b$ & $4.32 \mathrm{a}$ \\
\hline Total content of chlorophyll ( $\mathrm{mg} / \mathrm{g}$ fresh mass) & $4.67 \mathrm{a}$ & $0.85 b$ & $0.79 \mathrm{~b}$ & $8.17 \mathrm{a}$ \\
\hline
\end{tabular}

${ }^{*}$ In each crop, results with the same letter are not statistically different ( $t$-test, $p>0.05$ ).

in Heath and Packer (1968). To determine the levels of chlorophyll pigments, extraction was carried out with $5.0 \mathrm{ml}$ acetone $(80 \%$, v:v). The samples were centrifuged $\left(12,000 \mathrm{rpm}, 4^{\circ} \mathrm{C}, 15 \mathrm{~min}\right)$ and supernatants collected and absorbances at 647 and $664 \mathrm{~nm}$ recorded.

Phenolic compounds were extracted and quantified using a spectrophotometer by a colorimetric method based on reaction with Folin Ciocalteu reagent (mg gallic acid equivalents per $\mathrm{g}$ fresh mass). Malondialdehyde and other aldehydes were quantified by a colorimetric method based on reaction with thiobarbituric acid.

\section{Statistical analyses}

SPSS (Version 17.0 for Windows) was used to perform $t$, ANOVA and Tukey test $(p \leq 0.05)$. For the statistical analysis only, percentages of plant survival were transformed according to $y^{\prime}=2^{*} \arcsin (y / 100)^{05}$ to reach normality (Kolmogorov-Smirnov) and variancehomogeneity (Levene).

Fisher's linear discriminant functions were generated from the data matrix recorded in this research ( 48 cases $=4$ types of stress (salinity, high temperature, drought and waterloging) $\mathrm{x} 2$ plants (maize and common bean) $\mathrm{x} 2$ experimental conditions (control and stressing treatment) $\mathrm{x} 3$ replications). Eight variables were considered: levels of phenolics (free, cell-wall linked and total), malondialdehyde, other aldehydes and chlorophylls ( $a, b$ and total). SPSS was also used to obtain the Fisher'slinear discriminant functions.

\section{Results}

\section{Survival response to different levels of stress}

The effect of salt stress on maize and common bean is shown in Fig. 1. Both crop species are susceptible to dosages higher than $400 \mathrm{mM} \mathrm{NaCl}$ (Fig. 1C, E). Although plant survival at $600 \mathrm{mM}$ $\mathrm{NaCl}$ was lower in common bean than in maize this was not significant (Fig. 1D). In contrast, common bean plantlets showed higher tolerance to heat stress than maize (Fig. 2). In maize, plant survival decreased significantly with exposure to $40{ }^{\circ} \mathrm{C}$ for more than $3 \mathrm{~h}$; whereas this reduction was very slight in common bean plantlets up to $9 \mathrm{~h}$ of treatment (Fig. 2C). When the time of exposure to heat stress is considered an independent factor; that is plantlets of both species are pooled, $50 \%$ survival was observed after $9.3 \mathrm{~h}$ of treatment (Fig. 2E). Additionally, common bean plantlets tolerated longer periods without irrigation than maize (Fig. 3C). A significant reduction in plant survival was observed after $24 \mathrm{~h}$ in maize and $48 \mathrm{~h}$ in common bean (Fig. 3E). Finally, plantlet survival was not affected up to $10 \mathrm{~d}$ waterlogging conditions in either species (Fig. 4).

\section{Biochemical changes produced by stresses}

Phenolic compounds, aldehydes and chlorophylls were assessed in middle-aged leaves from plants surviving 72 hours of treatment with $567 \mathrm{mM} \mathrm{NaCl}$ conditions which caused 50\% 
594

Table 4. Effect of waterlogging on maize and common bean plantlets at $51.8 \mathrm{~h}$ of stress

\begin{tabular}{lcccc}
\hline \multirow{2}{*}{ Indicators evaluated in middle-aged leaves } & \multicolumn{2}{c}{ Maize } & \multicolumn{2}{c}{ Common bean } \\
\cline { 2 - 5 } & $25 \mathrm{ml}$ water/day & Flooded & $25 \mathrm{ml}$ water/day & Flooded \\
\hline Free phenolics (mg gallic acid equivalents/g fresh mass) & $1.80 \mathrm{~b}$ & $12.14 \mathrm{a}$ & $9.69 \mathrm{~b}$ & $10.33 \mathrm{a}$ \\
Cell wall-linked phenolics (mg gallic acid equivalents/g fresh mass) & $86.03 \mathrm{a}$ & $43.54 \mathrm{~b}$ & $43.82 \mathrm{~b}$ & $57.47 \mathrm{a}$ \\
Total content of phenolics $(\mathrm{mg}$ gallic acid equivalents/g fresh mass) & $87.82 \mathrm{a}$ & $55.68 \mathrm{~b}$ & $53.52 \mathrm{~b}$ & $67.80 \mathrm{a}$ \\
Malondialdehyde $(\mu \mathrm{M} / \mathrm{g}$ fresh mass) & $22.72 \mathrm{a}$ & $20.67 \mathrm{~b}$ & $55.30 \mathrm{a}$ & $51.61 \mathrm{~b}$ \\
Other aldehydes $(\mu \mathrm{M} / \mathrm{g}$ fresh mass) & $81.14 \mathrm{~b}$ & $83.52 \mathrm{a}$ & $129.54 \mathrm{~b}$ & $272.39 \mathrm{a}$ \\
Chlorophyll $a(\mathrm{mg} / \mathrm{g}$ fresh mass) & $2.96 \mathrm{a}$ & $0.34 \mathrm{~b}$ & $0.23 \mathrm{~b}$ & $1.84 \mathrm{a}$ \\
\hline Chlorophyll $b$ (mg/g fresh mass) & $1.78 \mathrm{a}$ & $0.22 \mathrm{~b}$ & $0.53 \mathrm{~b}$ & $1.14 \mathrm{a}$ \\
Total content of chlorophyll $(\mathrm{mg} / \mathrm{g}$ fresh mass) & $4.67 \mathrm{a}$ & $0.52 \mathrm{~b}$ & $0.79 \mathrm{~b}$ & $2.95 \mathrm{a}$ \\
\hline
\end{tabular}

${ }^{*}$ In each crop, results with the same letter are not statistically different ( $\mathrm{t}$-test, $\left.\mathrm{p}>0.05\right)$.

Table 5. Classification as non-stressed or stressed made by Fisher's discriminant functions

\begin{tabular}{|c|c|c|c|c|c|c|c|}
\hline \multirow{2}{*}{$\begin{array}{l}\text { Type of stress } \\
\text { evaluated }\end{array}$} & \multirow[b]{2}{*}{ Plant } & & \multicolumn{5}{|c|}{ Results of discriminant functions } \\
\hline & & & \multicolumn{2}{|l|}{$\begin{array}{l}\text { Function for non- } \\
\text { stressed }\end{array}$} & \multirow{2}{*}{$\begin{array}{c}\begin{array}{c}\text { Function for } \\
\text { stressed }\end{array} \\
74.70\end{array}$} & \multicolumn{2}{|c|}{$\begin{array}{l}\text { Classification according to } \\
\text { discriminant functions }\end{array}$} \\
\hline \multirow{12}{*}{ Salinity } & \multirow{7}{*}{ Maize } & \multirow{4}{*}{$0 \mathrm{mM} \mathrm{NaCl}$} & 89.35 & $>$ & & Non-stressed & Correct \\
\hline & & & 97.74 & $>$ & 80.02 & Non-stressed & Correct \\
\hline & & & 100.32 & $>$ & 81.59 & Non-stressed & Correct \\
\hline & & & 5.71 & $<$ & 34.58 & Stressed & Correct \\
\hline & & \multirow[t]{3}{*}{$567 \mathrm{mM} \mathrm{NaCl}$} & 3.44 & $<$ & 33.39 & Stressed & Correct \\
\hline & & & 9.04 & $<$ & 36.93 & Stressed & Correct \\
\hline & & & 96.55 & $>$ & 79.93 & Non-stressed & Correct \\
\hline & \multirow{5}{*}{$\begin{array}{l}\text { Common } \\
\text { bean }\end{array}$} & \multirow[t]{2}{*}{$0 \mathrm{mM} \mathrm{NaCl}$} & 92.18 & $>$ & 77.22 & Non-stressed & Correct \\
\hline & & & 96.26 & $>$ & 79.50 & Non-stressed & Correct \\
\hline & & \multirow{3}{*}{$567 \mathrm{mM} \mathrm{NaCl}$} & 12.91 & $<$ & 32.76 & Stressed & Correct \\
\hline & & & 9.91 & $<$ & 30.82 & Stressed & Correct \\
\hline & & & 6.45 & $<$ & 28.77 & Stressed & Correct \\
\hline \multirow{11}{*}{$\begin{array}{l}\text { High } \\
\text { temperature }\end{array}$} & \multirow{7}{*}{ Maize } & \multirow{4}{*}{$28^{\circ} \mathrm{C}$} & 98.78 & $>$ & 88.65 & Non-stressed & Correct \\
\hline & & & 101.28 & $>$ & 90.14 & Non-stressed & Correct \\
\hline & & & 101.31 & $>$ & 90.22 & Non-stressed & Correct \\
\hline & & & 40.23 & $<$ & 48.48 & Stressed & Correct \\
\hline & & \multirow[t]{3}{*}{$40{ }^{\circ} \mathrm{C}$} & 39.85 & $<$ & 48.40 & Stressed & Correct \\
\hline & & & -8.25 & $<$ & 18.61 & Stressed & Correct \\
\hline & & & 98.33 & $>$ & 82.27 & Non-stressed & Correct \\
\hline & \multirow{6}{*}{$\begin{array}{l}\text { Common } \\
\text { bean }\end{array}$} & $28^{\circ} \mathrm{C}$ & 96.65 & $>$ & 81.33 & Non-stressed & Correct \\
\hline & & & 93.10 & $>$ & 79.22 & Non-stressed & Correct \\
\hline & & & 51.01 & $<$ & 62.14 & Stressed & Correct \\
\hline & & $40^{\circ} \mathrm{C}$ & 49.55 & $<$ & 61.20 & Stressed & Correct \\
\hline \multirow{13}{*}{ Drought } & & & 51.42 & $<$ & 62.22 & Stressed & Correct \\
\hline & & & 89.35 & $>$ & 74.70 & Non-stressed & Correct \\
\hline & \multirow{5}{*}{ Maize } & $25 \mathrm{ml}$ water/day & 97.74 & $>$ & 80.02 & Non-stressed & Correct \\
\hline & & & 100.32 & $>$ & 81.59 & Non-stressed & Correct \\
\hline & & & 45.85 & $<$ & 54.35 & Stressed & Correct \\
\hline & & Lack of irrigation & 36.74 & $<$ & 48.78 & Stressed & Correct \\
\hline & & & 41.29 & $<$ & 51.41 & Stressed & Correct \\
\hline & & & 96.55 & $>$ & 79.93 & Non-stressed & Correct \\
\hline & & $25 \mathrm{ml}$ water/day & 92.18 & $>$ & 77.22 & Non-stressed & Correct \\
\hline & Common & & 96.26 & $>$ & 79.50 & Non-stressed & Correct \\
\hline & bean & & 51.01 & $<$ & 62.14 & Stressed & Correct \\
\hline & & Lack of irrigation & 49.55 & $<$ & 61.20 & Stressed & Correct \\
\hline & & & 51.42 & $<$ & 62.22 & Stressed & Correct \\
\hline & & & 89.35 & $>$ & 74.70 & Non-stressed & Correct \\
\hline & & $25 \mathrm{ml}$ water/day & 97.74 & $>$ & 80.02 & Non-stressed & Correct \\
\hline & Maize & & 100.32 & $>$ & 81.59 & Non-stressed & Correct \\
\hline & Maize & & 40.09 & $<$ & 47.17 & Stressed & Correct \\
\hline & & Flooded & 38.04 & $<$ & 46.03 & Stressed & Correct \\
\hline Waterlogging & & & 32.66 & $<$ & 42.45 & Stressed & Correct \\
\hline W aterlogging & & & 96.55 & $>$ & 79.93 & Non-stressed & Correct \\
\hline & & $25 \mathrm{ml}$ water/day & 92.18 & $>$ & 77.22 & Non-stressed & Correct \\
\hline & Common & & 96.26 & $>$ & 79.50 & Non-stressed & Correct \\
\hline & bean & & 58.89 & $<$ & 67.09 & Stressed & Correct \\
\hline & & Flooded & 56.57 & $<$ & 65.83 & Stressed & Correct \\
\hline & & & 40.44 & $<$ & 55.68 & Stressed & Correct \\
\hline
\end{tabular}




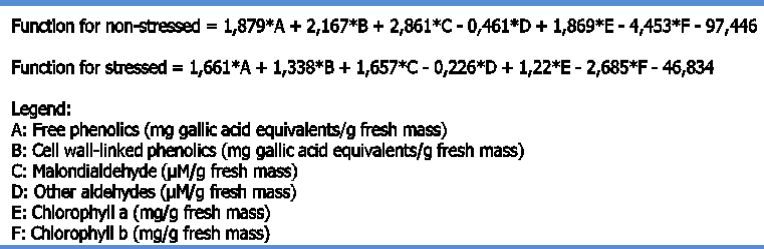

Fig. 5. Fisher's linear discriminant functions to differentiate non-stressed and stressed materials

plantlet death as calculated from Fig. 1E and compared to levels in the corresponding non-stressed controls. In general, salt stress induced statistically significant changes in the levels of all indicators with the exception of chlorophyll $b$ contents in maize, although in most cases these changes were relatively small. The most remarkable effects of abiotic stresses can be summarized as follows. The salinity stress treatment produced an 8-fold increase in free phenolics in maize and between 3 and 4 -fold increases in chlorophyll content ( $a, b$, and total) in common bean (Table 1$)$. On the other hand, maize and common bean responded differently to heat stress in the levels of biochemical markers (Table 2). In common bean, when biochemical marker expression was assessed after $40^{\circ} \mathrm{C}$ treatment for $9.3 \mathrm{~h}$ a 6 -fold decrease in free phenolics and a 20 -fold reduction of chlorophylls $(a, b$, and total) compared to the control was observed. In contrast, chlorophyll levels increased in maize between 5 and 10fold under the same conditions. Moreover, fifty percent of all plantlets died $51.8 \mathrm{~h}$ after irrigation was suspended (Fig. 3E). Under these conditions, the most relevant observed changes in biochemical marker levels were a 7 -fold increase in free phenolic compounds and a 5-fold reduction in chlorophyll contents $(a, b$, and total) in maize, and an increased in chlorophyll levels in common bean (Table 3). In the waterlogging stress experiment, biochemical evaluations were made $51.8 \mathrm{~h}$ post water immersion; a time that coincided with $50 \%$ plant death under drought. Similar to drought stress, waterlogging induced an increase in free phenolics and a decrease in chlorophyll levels in maize, while chlorophylls increased in common bean (Table 4).

In general, free phenolics tended to increase in maize under stress (salinity, drought and waterlogging) whereas chlorophylls decreased, particularly under drought and waterlogging. In contrast, chlorophyll levels in common bean increased under stress (salinity, drought and waterlogging). However, heat stress elicited a different response in both maize and common bean. Under high temperature, chlorophyll increased in maize while free phenolics decreased in common bean.

The statistical package-generated discriminant functions are shown in Fig. 5. Total contents of phenolics and chlorophylls were disregarded by SPSS. Requirements of this kind of analysis were met. Groups of the dependent variable were mutually excluded: plants were submitted or not to stress. Therefore, the dependent variable was not metrical but categorical Independent variables (biochemical compound levels) were all metrical. The number of cases (48) was higher than twice the number of variables (8). Equality of covariance matrixes was reached (Box test, $p>0.05$ ). Results from both functions were compared and they classified correctly $100 \%$ of non-stressed or stressed originally grouped plants (Table 5 ).

\section{Discussion}

One of the first and more general responses of plants to abiotic stress is the inhibition of growth, since plants redirect all their resources (energy and metabolic precursors) to defense reactions against stress (Baker, 1993; Grattan and Grieve, 1999; Ullrich, 2002; Xiong and Zhu, 2002). This phenomenon has been reported under salinity stress (Munns, 2005), waterlogging (Lopez and Kursar, 2003; Mielke et al., 2003), drought (Chao et al., 2006) and high temperature (Ribeiro et al., 2004). Furthermore, biochemical and physiological responses to the above stresses have been observed.

In our experiments, free phenolics and chlorophylls, especially $a$, were the most affected indicators and therefore can be regarded as potential abiotic stress biochemical markers. Leaf chlorophyll content was affected by salinity in tetraploid wheat (Munns and James, 2003), rice (Sultana et al., 1999), Brassica oleracea (Bhattacharya et al., 2004), Brassica juncea (Qasim, 1998) and Brassica napus (Pak et al., 2009). Salinity can affect chlorophyll content through inhibition of chlorophyll synthesis or an acceleration of its degradation (Zhao et al., 2007). Thioyapong et al. (2004) found that the chlorophyll losses due to salinity stress is consistent with possible differences in reactive oxygen species (ROS) production among the genotypes and suggested that in salt sensitive genotypes, ROS scavenging systems were unable to detoxify ROS generated. Our results do not support these findings as common bean chlorophyll levels increased under salinity (Table $1)$.

According to Baker (1993), changes in the photochemical efficiency of plants under drought may be assessed by the analysis of chlorophyll $a$ fluorescence efficiency associated with photosystem II. Under stress, a decrease in the ratio of variable fluorescence / maximum fluorescence has been attributed to the inactivity of the photosystem II reaction centers due to the degradation of the D1 and D2 proteins responsible for the transfer of water electrons to chlorophyll $a$ associated with the photosystem II reaction center (Hao et al., 1999; Lazár, 1999). Chlorophyll content could therefore, be correlated to chlorophyll fluorescence thus indicating its suitability as a future biochemical marker. Abiotic stresses decrease photosynthesis, mainly by limiting $\mathrm{CO}_{2}$ entrance to leaves through stomatal closure. Moreover, membrane systems containing chlorophylls are destabilized affecting the luminous phase thus leading to increased synthesis of chlorophylls that are unable to fix more $\mathrm{CO}_{2}$ (Hörtensteiner, 2006; Hörtensteiner and Kräutler, 2011).

A consequence of the abiotic stress-induced limitation of photosynthesis is the exposure of plants to excess energy, which, if not safely dissipated, may be harmful to photosystem II because of over reduction of the reaction centers (Demmig-Adams and Adams, 1992) and increased production of ROS in the chloroplasts (Smirnoff, 1993). On the other hand excess energy could be used to synthesize secondary metabolites as suggested by Selmar and Kleinwächter (2013).

Phenolic compounds and flavonoids are among the most influential and widely distributed secondary products in the plant kingdom (Ali and Abbas, 2003). Many play important physiological and ecological roles and are involved in resistance to different types of stress (Ayaz et al., 2000). These metabolites have several defense functions and, therefore, their biosynthesis in plants is generally induced in response to biotic and abiotic stimuli such as UV-B radiation, drought, chilling, ozone, heavy metals, and attacks by pathogens, wounding, or nutrient deficiency (Bettaieb et al., 2011; Dixon and Paiva, 1995; Grace, 2005)

Our results indicated that free phenolics and chlorophylls, especially $a$, were the most responsive indicators. The differences recorded between maize and common bean is to some extent a 
596

function of their differences in photosynthetic efficiency, however there may also be a genotype within species effect. We have hypothesized that, in stressed plants, levels of free phenolics and chlorophylls first increase and subsequently decrease. However, such changes take place in different time frames depending on the plant species and genotype. In the experiments shown here, moderate and severe stress conditions were applied that did not necessarily represent any specific natural environment, but were used for selection purposes only. In follow-up experiments, mild to moderate stress conditions may enable plant metabolism to respond properly to the respective stress conditions. Further studies are in progress to determine the practical use of free phenolics, chlorophylls and other biochemical markers for stress tolerance in breeding programs.

The Fisher's linear discriminant functions shown in this paper (Fig. 5) are important tools for those breeding programs focused on the production of abiotic stress-tolerant plants. Maize and common bean seeds of new genotypes can be grown for 10 days and then stressed or not as described here. Levels of phenolics (free and cell-wall linked), malondialdehyde, other aldehydes and chlorophylls $(a, b)$ are determined. Such new data are evaluated in both discriminant functions. If the resulting value of the stressed discriminant function is similar to that of the non-stressed discriminant function, the new genotype can be regarded as putatively tolerant, as it shows similar physiology under either nonstressing or stressing conditions. Although the new genotype tolerance still requires additional confirmation under a field environment, the results described here allow some research cost reductions because there is no inclusion of a large number of susceptible cultivars in expensive field trials. At present, this research group is carrying out further experiments to know if these discriminant functions can be used in other plant species.

Discriminant analysis is useful for situations where the building of a predictive model of group membership based on observed characteristics of each case is desirable. The procedure generates discriminant functions based on linear combinations of the predictor variables, which provide the best discrimination between groups. The functions are generated from a sample of cases for which group membership is known. The functions can then be applied to new cases with measurements for the predictor variables but unknown group membership (Bantte and Prasanna, 2003; Cardi, 1998; Daoyu and Lawes, 2000; Figlivolo et al., 2001; Somersalo, 1998; Teshome et al., 1997). The use of this kind of analysis for differentiation of non-stressed or stressed plants is a novel aspect of this report that can be applied for early selection of plant tolerance to abiotic factors.

\section{Acknowledgments}

This research was supported by the Bioplant Centre (University of Ciego de Avila, Cuba). We are grateful to $\mathrm{Mr}$. Arnaldo Trujillo, Mr. Orleans González, Mrs. Alitza Iglesias, Mr. Gustavo Lorente, Mrs. Laritza Torreblanca and Mr. Carlos Leiva for their excellent technical assistance; and to Mrs. Glyn Jabour for the professional language edition. This research was also partially supported by the Australia Award Fellowship, and by the German Academic Exchange Service (DAAD) through grants to Dr. José Carlos Lorenzo Feijoo.

\section{References}

Abdelgadir E, Oka M, Fujiyama H (2005). Characteristics of nitrate uptake by plantsunder salinity. Journal of Plant Nutrition 28:33-46.

Ali RM, Abbas HM (2003). Response of salt stress barley seedlings to phenylurea. Plant, Soil and Environment 49:158-162.

Anderson C, Kohorn B (2001). Inactivation of Arabidopsis SIP1 leads to reduced levels of sugars and drought tolerance. Journal of Plant Physiology 158:1215-1219.

Anjum SA, Wang LC, Farooq M, Hussain M, Xue LL, Zou CM (2011). Brassinolide application improves the drought tolerance in maize through modulation of enzymatic antioxidants and leaf gas exchange. Journal of Agronomy and CropScience 197:177-185.

Arbona V, Marco AJ, Iglesias DJ, López-Climent MF, Talon M, GómezCadenas A (2005). Carbohydrate depletion in roots and leaves of saltstressed potted Citrus dementina L. Plant Growth Regulation. 46:153160.

Ayaz FA, Kadioglu A, Turgut R (2000). Water stress effects on the content of low molecular weight carbohydrates and phenolic acids in Ctenanthe setose (Rosc.) Eichler. Canadian Journal of Plant Science 80:373-378.

Baker N (1993). Light-use efficiency and photoinhibition of photosynthesis in plants under environmental stress. In: Smith J, Griffiths H (Eds). Water Deficits Plant Responses from Cell to Community. Bios Scientific Publisher, Oxford pp 221-235.

Bantte K, Prasanna BM (2003). Simple sequence repeat polymorphism in quality protein maize (QPM) lines. Euphytica 129:337-344.

Benhassaini H, Fetati A, Hocine AK, Belkhodja M (2012). Effect of salt stress on growth and accumulation of proline and soluble sugars on plantlets of Pistacia atlantica Desf. subsp. atlantica used as rootstocks. Biotechnology, Agronomy, Society and Environment 16:159-165.

Bettaieb I, Bourgou S, Hamrouni-Sellami I, Limam F, Marzouk B (2011). Drought effects on polyphenol composition and antioxidant activities in aerial parts of Salvia officinalis L. Acta Physiologiae Plantarum 33:1103-1111.

Bhattacharya R, Maheswari M, Dineshkumar V, Kirti P, Bhat S, Chopra V (2004). Transformation of Brassica olaracea var. capitata with bacterial bet $A$ gene enhances tolerance to salt stress. Scientia Horticulturae 100:215-227.

Cardi T (1998). Multivariate analysis of variation among Solanum commersonii (+) S. tuberosum somatic hybrids with different ploidy levels. Euphytica 99:35-41.

Celik G, Turhan E (2011). Genotypic variation in growth and physiological responses of common bean (Phaseolus vulgaris L.) seedlings to flooding. African Journal of Biotechnology 10:7372-7380.

Colmer T, Voesenek L (2009). Flooding tolerance: suites of plant traits in variable environments. Functional Plant Biology 36:665-681.

Crafts-Brandner SJ, Salvucci ME (2002). Sensitivity of photosynthesis in a $\mathrm{C}_{4}$ plant, maize, to heat stress. Plant Physiology 129:1773-1780. 
Chao S, Kim J, Jong AP, Eom TJ, Kim WT (2006). Constitutive expression of abiotic stress-inducible hot pepper CaXTH3, which encodes a xyloglucan endotransglycosylase/hydrolase homolog, improves drought and salt tolerance in transgenic Arabidopsis plants. FEBS Letters 580:3136-3144.

Daoyu Z, Lawes GS (2000). Manova and discriminant analyses of phenotypic data as a guide for parent selection in kiwifruit (Actinidia deliciosa) breeding. Euphytica 114:151-157.

Demmig-Adams B, Adams WW (1992). Photoprotection and other responses of plants to high light stress. Annual Review of Plant Physiology and Plant Molecular Biology 43:599-626.

Díaz-López L, Gimeno V, Simón I, Martínez V, RodríguezOrtega WM, García-Sánchez F (2012a). Jatropha curcas seedlings show a water conservation strategy under drought conditions based on decreasing leaf growth and stomatal conductance. Agricultural Water Management 105:48-56.

Díaz-López L, Gimeno V, Lidón V, Simón I, Martínez V, GarcíaSánchez F (2012b). The tolerance of Jatropha curcas seedlings to $\mathrm{NaCl}$ : an ecophysiological analysis. Plant Physiology and Biochemistry 54:34-42.

Dixon RA, Paiva NL (1995). Stress-induced phenylpropanoid metabolism. Plant Cell 7:1085-1097.

FAOSTAT (2013). Statistical database of the food and agriculture of the United Nations. FAO, Rome, Italy.

Fenta BA, Beebe SE, Rao IM, Kunert KJ (2014). Association of nodule performance traits with shoot performance traits of common bean under drought stress. Journal of Crop Improvement 28:418-435.

Figlivolo G, Candido V, Logozzo G, Miccolis V, Spagnoletti PL (2001). Genetic evaluation of cultivated garlic germplasm (Allium sativum L. and A. ampeloprasum L.). Euphytica 121:325-334.

Foyer C, Noctor G (2000). Oxygen processing in photosynthesis: regulation and signaling. New Phytologist 146:359-388.

Galle A, Haldimann P, Feller U (2007). Photosynthetic performance and water relations in young pubescent oak (Quercus pubescens) trees during drought stress and recovery. New Phytologist 174:799-810.

Gama PBS, Inanaga S, Tanaka K, Nakazawa R (2007). Physiological response of common bean (Phaseolus vulgaris L.) seedlings to salinity stress. African Journal of Biotechnology 6:79-88.

Gepts P, Beavis W, Brummer E, Shoemaker R, Stalker H, Weeden $\mathrm{N}$, Young N (2005). Legumes as a model plant family. Genomics for food and feed report of the cross legume advances through genomics conference. Plant Physiology 137:1228-1235.

Gimeno V, Syvertsen J, Simón I, Nieves M, Díaz-López L, Martínez V, García-Sánchez F (2012). Physiological and morphological responses to flooding with fresh or saline water in Jatropha curcas. Environmental and Experimental Botany 78:47-55.

Gindaba J, Rozanov A, Negash L (2004). Response of seedlings of two Eucalyptus and three deciduous tree species from Ethiopia to severe water stress. Forest Ecology and Management 201:119-129.

Grace S (2005). Phenolics as antioxidants. In: Smirnoff N (Ed). Antioxidants and Reactive Oxygen Species in Plants. Blackwell, Oxford pp 141-168.

Grattan S, Grieve C (1999). Mineral nutrient acquisition and response by plants grown in saline environments. In: Pessarakli M (Ed). Handbook of Plant and Crop Stress. Marcel Dekker, New York, Basel pp 203-229.

Gurmani AR, Bano A, Saleem M (2007). Effect of ABA and BA on growth and ion accumulation of wheat under salinity stress. Pakistan Journal of Botany 39:141-149.

Gurr S, McPherson J, Bowles D (1992). Lignin and associated phenolic acids in cell walls. In: Wilkinson DL (Ed). Molecular Plant Pathology. Oxford Press, Oxford pp 51-56.

Hao L, Liang H, Wang Z, Liu X (1999). Effects of water stress and rewatering on turnover and gene expression of photosystem II reaction center polypeptide D1 in Zea mays. Australian Journal of Plant Physiology 26:375-378.

Heath R, Packer J (1968). Photoperoxidation in isolated chloroplast: I. Kinetics and stoichiometry of fatty acid peroxidation. Archives of Biochemistry and Biophysics. 125:189-198.

Hörtensteiner S (2006). Chlorophyll degradation during senescence. Annual Review of Plant Biology 57:55-77.

Hörtensteiner S, Kräutler B (2011). Chlorophyll breakdown in higher plants. Biochemistry and Biophysics Acta 1807:977988.

Huang XY, Chao DY, Gao JP, Zhu MZ, Shi M, Lin HX (2009). A previously unknown zinc finger protein, DST, regulates drought and salt tolerance in rice via stomatal aperture control. Genes and Development 23:1805-1817.

Hungria M, Kaschuk G (2014). Regulation of $\mathrm{N}_{2}$ fixation and $\mathrm{NO}_{3}{ }^{-} / \mathrm{NH}_{4}^{+}$assimilation in nodulated and $\mathrm{N}$-fertilized Phaseolus vulgaris L. exposed to high temperature stress. Environmental and Experimental Botany 98:32-39.

ISTA (2005). International Rules for Seed Testing International Seed Testing Association. Bassersdorf, Switzerland.

Lazár D (1999). Chlorophyll a fluorescence induction. Biochimica et Biophysica Acta 1412:1-28.

Lopez O, Kursar T (2003). Does flood tolerance explain tree species distribution in tropical seasonally flooded habitats? Oecologia 136:193-204.

Medina CL, Sanches MC, Tucci MLS, Sousa CAF, Cuzzuol GRF, Joly CA (2009). Erythrina speciosa (LeguminosaePapilionoideae) under soil water saturation: morphophysiological and growth responses. Annals of Botany 104:671-680.

Mielke M, Almeida A, Gomes F, Aguilar M, Mangabeira P (2003). Leaf gas exchange, chlorophyll fluorescence and growth responses of Genipa americana seedlings to soil flooding. Environmental and Experimental Botany 50:221-231. 
598

Munns R (2005). Genes and salt tolerance: bringing them together. New Phytologist 167:645-663.

Munns R, James R (2003). Screening method for salinity tolerance: A case study with tetraploid wheat. Plant Soil 253:201-218.

Omoto E, Taniguchi M, Miyake H (2012). Adaptation responses in $\mathrm{C}_{4}$ photosynthesis of maize under salinity. Journal of Plant Physiology 169:469-477.

Osmond CB, Austin MP, Berry JA, Billings WD, Boyer JS, Dacey JWH, Nobel PS, Smith SD, Winner WE (1987). Stress physiology and the distribution of plants. BioScience 38-48.

Pak V, Nabipour M, Meskarbashee M (2009). Effects of salt stress on chlorophyll content, fluorescence, $\mathrm{Na}^{+} \mathrm{y} \mathrm{K}^{+}$ions content in rape plants (Brassica napus L.). Asian Journal of Agricultural Research 3:28-37.

Porra R (2002). The chequered history of the development and use of simultaneous equations for the accurate determination of chlorophylls $a$ and $b$. Photosynthesis Research 73:149-156.

Qasim A (1998). Effect of salinity on growth, proline accumulation and chlorophyll content during vegetative growth, flowering and seed formation of Brassica juncea L. Agricultural Science 10:145-152.

Qing DJ, Lu HF, Li N, Dong HT, Dong DF, Li YZ (2009). Comparative profiles of gene expression in leaves and roots of maize seedlings under conditions of salt stress and the removal of salt stress. Plant Cell Physiology 50:889-903.

Quan R, Shang M, Zhang H, Zhao Y, Zhang J (2004). Engineering of enhanced glycine betaine synthesis improves drought tolerance in maize. Plant Biotechnology Journal 2:477-486.

Ribeiro R, Machado E, Oliveira R (2004). Growth and leaf temperature effects on photosynthesis of sweet orange seedlings infected with Xylella fastidiosa. Plant Pathology 53:334-340.

Ribeiro R, Machado E, Santos M, Oliveira R (2009). Seasonal and diurnal changes in photosynthetic limitation of young sweet orange trees. Environmental and Experimental Botany 66:203-211.

Rivelli A, De Maria S, Pizza S, Gherbina P (2012). Growth and physiological response of hydroponically grown sunflower as affected by salinity and magnesium levels. Journal of Plant Nutrition 33:1307-1323.

Schachtman D, Goodger J (2008). Chemical root to shoot signaling under drought. Trends in Plant Science 13:281-287.

Selmar D, Kleinwächter M (2013). Influencing the product quality by deliberately applying drought stress during the cultivation of medicinal plants. Indian Crops Production 42:558- 566.

Shafi M, Bakht J, Khan M, Khan M, Raziuddin M (2011). Role of abscisic acid and proline in salinity tolerance of wheat genotypes. Pakistan Journal of Botany 43:1111-1118.

Silva EN, Ferreira-Silva SL, Viégas RA, Silveira JAG (2010a). The role of organic and inorganic solutes in the osmotic adjustment of drought-stressed Jatropha curcas plants. Environmental and Experimental Botany 69(3):279-285.

Silva EN, Ferreira-Silva SL, de Vasconcelos Fontenele A, Ribeiro RV, Viégas RA, Silveira JAG (2010b). Photosynthetic changes and protective mechanisms against oxidative damage subjected to isolated and combined drought and heat stresses in Jatropha curcas plants. Journal of Plant Physiology 167(14):1157-1164.

Smirnoff N (1993). The role of active oxygen in the response of plants to water deficit and desiccation. New Phytologist 125:27-58.

Somersalo S (1998). Morpho-physiological traits characterizing environmental adaptation of Avena barbata. Euphytica 99:213-220.

Subbaiah CC, Sachs MM (2002). Molecular and cellular adaptations of maize to flooding stress. Annals of Botany 91:119-127.

Sultana N, Ikeda T, Itoh R (1999). Effect of $\mathrm{NaCl}$ salinity on photosynthesis and dry matter accumulation in developing rice grains. Environmental and Experimental Botany 42:211220.

Teshome A, Baum BR, Fahrig L, Torrance JK, Arnason TJ, Lambert JD (1997). Sorghum [Sorghum bicolor(L.) Moench] landrace variation and classification in North Shewa and South Welo, Ethiopia. Euphytica 97:255-263.

Thioyapong P, Melkonian J, Wolf D, Steffens J (2004). Suppression of polyphenol oxidases increases stress tolerance in tomato. Plant Science 167:693-703.

Tilman D, Cassman KG, Matson PA, Naylor R, Polasky S (2002). Agricultural sustainability and intensive production practices. Nature 418:671-677.

Ullrich W (2002). Salinity and nitrogen nutrition. In: Lauchli A, Luttge U (Eds). Salinity: Environment-Plants-Molecules. Kluwer, Dordrecht pp 229-248.

Wetson A, Flowers T (2010). The effect of saline hypoxia on growth and ion uptake in Suaeda maritima. Functional Plant Biology 37:646-655.

William HM, Trethowan RM, Crosby-Galvan EM (2007). Wheat breeding assisted by markers: CIMMYT's experience. Euphytica 157:307-319.

Xiong L, Zhu JK (2002). Salt tolerance. In: Meyerowitz E, Somerville C (Eds). The Arabidopsis Book, Vol 24. American Society of Plant Biologists, Rockville, MD pp 1-22.

Xu Z-S, Xia L-Q, Chen M, Cheng X-G, Zhang R-Y, Li L-C (2007). Isolation and molecular characterization of the Triticum aestivum L. ethylene-responsive factor 1 (TaERF1) that increases multiple stress tolerance. Plant Molecular Biology 65:719-732.

Zhao G, Ma B, Ren C (2007). Growth, gas exchange, chlorophyll fluorescence and ion content of naked oat in response to salinity. Crop Science 47:123-131.

Zhu JK (2001). Plant salt tolerance. Trends in Plant Science 2:6671. 